\title{
LEXICON
}

\section{MACHIAVELLIAN PRINCIPLES DEPICTED IN WILLIAM SHAKESPEARE'S OTHELLO}

\author{
by: Raden Ayu Qisthi Shafira Sukardi (11/318517/SA/16047) \\ qisthishafiraaa@gmail.com \\ English Department, Universitas Gadjah Mada
}

\begin{abstract}
This research is aimed to identify Machiavellian principles applied in Iago's traits. Dynamic structuralism proposed by Mukarovsky is applied as its theoretical approach, so the discussion of this research evolves around the intrinsic elements of the play as well as the historical background of Machiavelli and the principles. By conducting a library research as the method, it is revealed that Machiavelli has his own idea to define power. According to Machiavelli, achieving power has to deal with virtù as a force. This is considered as the highlight of Machiavellian principles in this research.

Therefore, the interaction between Iago and other characters are analyzed to see the application of Machiavellian principles in Iago's traits. Iago's plan is highlighted and linked to Machiavellian principles, saying that it is acceptable for someone to be harmful and selfish as the ways to achieve power. As the result, this research concludes that Iago has various personalities: as a backstabber, a trickster, and a master of exploiting other people's mind. These personalities are aligned with Machiavellian principles. Iago manages a mischievous plan to destroy other people's lives. His atrocious behavior represents the idea of a Machiavellian virtùe, described as a part of Machiavellian principles.
\end{abstract}

Keywords: Machiavellian principles, dynamic structuralism, Iago, power, character

\section{Intisari}

Penelitian ini bertujuan untuk mengidentifikasi prinsip-prinsip Machiavelli yang terdapat dalam sifat-sifat Iago. Pendekatan teori yang digunakan adalah strukturalisme dinamik yang diujarkan oleh Mukarovsky, sehingga diskusi penelitian ini berkaitan dengan elemen-elemen intrinsik pada karya tersebut dan latar belakang sejarah Machiavelli dan prinsip-prinsipnya. Dengan menggunakan metode tinjauan pustaka, telah disimpulkan bahwa Machiavelli memiliki pandangannya sendiri mengenai kekuasaan. Menurut Machiavelli, kekuasaan harus berkaitan dengan virtù yang dijadikan sebagai sebuah tekanan untuk mendapat kekuasaan, terlihat dalam sifat-sifat Iago. Inilah yang dimaksud dari prinsip-prinsip Machiavelli dalam penelitian ini.

Oleh karena itu, interaksi diantara Iago dan karakter yang lain dianalisa untuk melihat kontribusinya terhadap alur cerita. Rencana Iago menjadi bahan analisis dan disambungkan dengan prinsip-prinsip Machiavelli yang menyatakan bahwa seseorang berhak melakukan perbuatan tidak menyenangkan pada orang lain sebagai sebuah cara untuk mendapat kekuasaan. Hasilnya, penelitian ini menyimpulkan bahwa Iago memiliki beragam kepribadian: sebagai seseorang yang menusuk punggung orang lain, seorang penipu, dan seorang ahli mengatur pikiran orang lain. Beragam kepribadian ini menggambarkan kemiripan dengan prinsip-prinsip Machiavelli, karena Iago berhasil melakukan rencana jahatnya untuk menghancurkan hidup orang lain. Perilakunya yang seperti itu mewakili pandangan Machiavelli terhadap seorang virtù yang merupakan bagian dari prinsip-prinsipnya.

Kata kunci: Prinsip-prinsip Machiavelli, strukturalisme dinamik, Iago, kekuasaan, karakter Raden Ayu Qisthi Shafira Sukardi 
William Shakespeare is a prominent playwright who produces many works during the late 1580s in England. According to Bate and Rasmussen (2009), his career begins as an actor (playing two roles; as the ghost in Hamlet and Adam in As You Like It), but he realizes that "he was never going to grow into a great comedian like Tarlton or a great tragedian like Alleyn" (198). Thus, after the theatres are closed because of the plague during the seasons of 1592-93, Shakespeare becomes one of the actors, writers and owners in a newly organized acting company sponsored by Lord Chamberlain, known as The Lord Chamberlain's Men, and later as the King's men (Bate and Rasmussen 149). His career evolves around the playhouses in London where people come to watch his play along the Borough of Southwark, "the site of the public theatres and other popular entertainments such as bear-baiting, cockfighting, and legal brothels" (Hebron 26). When the compilers of the First Folio, published in 1623, came to decide on the order in which they would print the plays, they divided them into Comedies, Histories, and Tragedies (Wells 105).

According to A.C. Bradley, Shakespearian tragedies are known as The Big Four: Hamlet (160001), Othello (1604), King Lear (1605-06), and Macbeth (1606). Othello as one of Shakespearean tragedies is interesting to be analyzed, because the whole story does not only involve the formal elements of tragedy such as hamartia, peripeteia, anagnoresis, and catharsis, but also introduces a complexity in positioning the role of the characters. There are many issues that can be observed just by analyzing the characters. However, this research is going to highlight Iago's traits. Iago is an interesting character to be investigated, because he actually drives the plot of the whole story and twists it with his revenge to Othello. Also, he plays an important role in creating problems among the characters that leads into a tragic end.

Having 272 speeches and 12 scenes on the stage (Bate and Rasmussen 23), Iago has his own charming way to hypnotize other characters and convince the readers/audiences to believe in him. He contributes to the idea of binary opposition that exists in Othello. Binary opposition is a pair of concepts that has opposite meaning and highlights the notion of otherness in Othello, such as black and white, good and evil, East and West. To some extent, Iago represents the twofaced man, a backstabber, who acts normally in front of his victims. Thus, these points are aligned with the notion of Machiavellian principles. According to The Oxford Dictionary of Literary Terms, Machiavel is a "type of stage villain found in Elizabethan and Jacobean drama and named after the political theorists Niccolò Machiavelli, whose notorious book Il Principe (The Prince, 1513) justified the use of dishonest means to retain state power." while Merriam Webster Dictionary (2015) defines the term "Machiavellian" as "the use of clever lies and tricks in order to get or achieve something". It is called Machiavellian, because the principles come from how Niccolo Machiavelli, a Florentine nobleman, observe people in power during Italy's downfall as a result of the invasion from France and Spain during his time of writing The Prince (Gauss 10). The main point of Machiavellian principles is it is often necessary for rulers to use supreme methods in order to achieve power and success. In this context, supreme methods serve the idea of negative senses that ignore other people's feelings. It is because the principles evolve around the idea of manipulating and corrupting others for the individual's personal gain.

To identify the Machiavellian principles in Iago's traits, this research is using dynamic structuralism proposed by Mukarovsky (1975) as its theoretical approach. It is not only approaching the intrinsic element of the play, but also the environment of the society such as cultural and historical background. This means that the analysis focuses largely on the primary data taken from the novel while the secondary data are also important to acquire a full comprehension of the novel. The data is collected by conducting a library research.

Therefore, this research focuses on how the literary work manifests itself to a certain layer in the society, political view in seeing how power should be gained. It highlights the historical background of Machiavelli that creates the concept of Machiavellian principles to see if they are applied in Iago's traits. Nonetheless, this undergraduate thesis is not going to identify all intrinsic area of the play. It covers only Iago's traits and their connection with Machiavellian principles, analyzing them from Iago's way to deliver his thoughts to the audience and influence other characters.

\section{MACHIAVELLI AND POWER}

In Philosophy, Machiavelli is known with the notion of rulership that represents the idea of virtù. According to Stanford Encyclopedia of Philosophy (Winter 2014 
edition), it is common for political philosophers to believe that there exists a special relationship between moral goodness and legitimate authority for a good ruler is the one who shows them to be virtuous and morally upright. Nonetheless, Machiavelli critizes that concept and believes that "there is no moral basis on which to judge the difference between legitimate and illegitimate uses of power" (Nederman, "Niccolò Machiavelli"). It is because "politics can coherently be defined in terms of the supremacy of coercive power: authority as a right to command has no independent status" (Nederman, "Niccolò Machiavelli). Nederman also states "without exception the authority of states and their laws will never be acknowledged when they are not supported by a show of power which renders obedience inescapable". The ways achieve the obedience are varied and depend on how coercive the person is. By any means, being evil is acceptable to gain power, even though it is harmful to others. As in Othello, being evil is defined as Iago's deception to show his disappointment for Othello promoted Cassio instead of him.

In The Art of War, Machiavelli also emphasizes that the existence of allies either in a military force or a political leadership does not compromise an everlasting relationship, because every one deserves to stab each other for gaining power. He shows that in classical politics, allies and opposition are blurred with the existing human ego in achieving power. For example, it is seen when Iago can position himself as Rodorigo's friend who uses his innocent feeling to Desdemona as a weapon to ruin Othello's life. Also, Emilia, who has helped Iago to take the handkerchief, finally reveals the truth about her husband's trickery and accuses Iago. Both events show the existence of allies who can turn into enemies.

In addition, according to Wood in his Introduction to The Art of War, the gap between two wars is a recess when conflicts are buried, waiting to explode. In Othello, when there seems to be no conflicts, it is actually the time for Iago to construct the calamity. The gap is obviously seen when the characters are still adjusting with a new place, moving from Venice to Cyprus. In Cyprus, the problems are developed until the bomb is finally exploded.

Moreover, the idea of virtù suggested by Machiavelli is different with how we define 'virtue'. It can be associated with an extreme devilish side of a person to achieve power by being selfish and being harmful to other people's lives (Wood lx). Machiavelli allows this kind of concept, because he believes that there are two standard markers of power, maintaining the state and achieving great things (Nederman, "Niccolò Machiavelli"). It is not authority and legitimacy that become important, but force. The force is seen from the abilities of the Machiavellian characters of the virtu to behave in a completely evil fashion.

Therefore, the way Machiavelli describes political situation at that time has many similarities with most events in Othello, especially the emergence of devilish side of the Machiavellian characters with Iago's traits.

\section{IAGO'S PLAN}

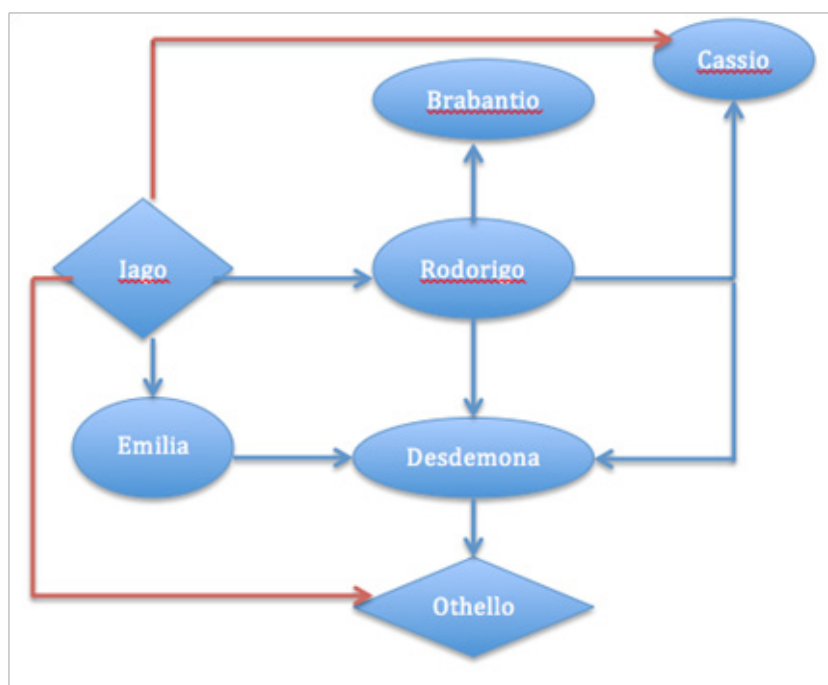

The previous chart shows how Iago contributes to the plot development. The red arrows show his main motives, taking over Cassio's position and taking revenge on Othello. In order to achieve both motives, Iago is taking advantage of other people, shown by the blue arrows. He constructs the calamity in other people's lives to gain power by becoming a virtù. The idea of virtù is mentioned in chapter two that Machiavelli associates it with an extreme devilish side of a person to achieve power by being selfish and being harmful to other people's lives. Having Iago done the exact same thing with the Machiavellian concept, Iago is portrayed as a virtu towards other characters in order to achieve power.

Iago is making use of Rodorigo, Brabantio, Emilia and Desdemona to take revenge on Othello and take over Cassio's position as a lieutenant. Iago tells Rodorigo to help him convince Brabantio that 
Othello is not a good husband for Desdemona. Iago emphasizes on Othello's race and otherness. In front of the Duke, Brabantio asks Othello to clarify the marriage. Othello is assumed to use witchcraft until Desdemona wants to marry her. Othello says that their love grows when Othello often comes to Brabantio's house and tells him about Othello's struggle in the past. Desdemona overhears the story and falls in love with Othello. Othello says that, "She [Desdemona] loved me for the dangers I had passed, / And I love her that she did pity them / This only is the witchcraft I have used." (1.3.181-183). The Duke asks Brabantio to believe in Othello, because that kind of story is going to win any daughters' heart. Brabantio does not want to accept the truth until Desdemona comes and conveys her thoughts about the wedding. Desdemona gives her father an explanation that Othello is her husband, and they are married for the sake of love without any force: "So much I challenge that I may profess / Due to the Moor my lord." (1.3.204-205). Brabantio hardly accepts the truth, but the Duke gives him an advice to forgive Othello and lets Desdemona live with the one she wants:

When remedies are past, the griefs are ended By seeing the worst, which late on hopes depended. To mourn a mischief that is past and gone Is the next way to draw new mischief on. (1.3.218221)

As a result, Iago's plan to bring the marriage to an end is failed. That is why Iago tries another way to destruct Othello's life by ruining the marriage between Othello and Desdemona. Iago uses Rodorigo to trigger conflicts with Cassio. Iago convinces Rodorigo that Cassio is having an affair with Desdemona. Iago tells Othello the same thing, so both Rodorigo and Othello hate Cassio. Also, Iago uses Emilia's position as Desdemona's servant to get the handkerchief for him. The handkerchief is a gift from Othello to Desdemona. Because of that, Iago wants to put the handkerchief in Cassio's place to convince Othello that the affair is really happening. As it happens, Iago's plan is working, because Othello's life is ruined by Iago who controls the chaotic situation. Things done by lago toward other characters in constructing disasters through their lives reflect his devilish side of personality, because Iago is selfish. He does not want to think about the risk he gives to other people, but his goals to take revenge on
Othello and replace Cassio in the military service.

Moreover, Iago wants Cassio's position very much, because the story is taken place during the war between Venice and Turkey. Othello's existence in Cyprus as a Venetian colonial country appears to be a thread to Turkey, and Iago feels that he deserves to be Othello's lieutenant instead of only Othello's flag-bearer. Iago is sure that he has a better military skill than Cassio who only "the bookish theoric" (1.1.24). He explains that he is more experienced than Cassio:

And I - of whom his eyes had seen the proof At Rhodes, at Cyprus, and on other grounds Christian and heathen - must be belee'd and calmed

By debitor and creditor: this counter-caster $\mathrm{He}$ - in good time - must his lieutenant be And I - bless the mark! - his Moorship's ancient (1.1.28-34)

This is a starting point of all the hatred Iago has towards Cassio and Othello, showing that position in the military service is very important at that time, not only to be considered as prestige, but also to prove how one can dedicate to his country. Iago also states that no matter how much he hates Othello, Othello is always considered as his master: "We cannot all be masters, nor all masters / Cannot be truly followed." (1.1.44-45). This shows that Iago's cunning acts are the examples of how varied people show their obedience to their country for maintaining power and the state. In addition, it is actually normal for the state to have an inescapable obedience to acknowledge the rules, knowing that people become more aware than they used to when someone tries to construct a chaotic society. For example, Emilia knows that she should return the handkerchief to Desdemona, but she is too late, because Iago comes right away to take it away from her. It is implied that Iago as an example of the inescapable obedience represents the Machiavellian notion of power and the state, described in the previous chapter.

Therefore, the occurrence of Iago's plan shows the importance of being a lieutenant in the military service for Iago until he decides to take revenge on Othello for choosing Cassio over him. Iago puts Rodorigo, Emilia, Desdemona and Brabantio through tough situation for his own benefits. 


\section{IAGO'S SOLILOQUY}

Soliloquy is a part of a Shakespearean tragedy. It is not only about how a character in a play speaks one's thought aloud, but also about how the character lets the audience perceive their understanding of the character's feeling when the other characters are not on the stage. Iago does two soliloquys throughout the story, and both of them are analyzed to prove that Iago is nice in front of other characters while he actually hates Othello and uses others to revenge on Othello. Iago's soliloquys are important to be analyzed, because they show Iago's honesty in expressing his thoughts about what he really feels. By any means, soliloquys speak the truth. Because of that, analyzing Iago's soliloquys is the same as highlighting the inconsistency of Iago's personalities throughout the play. One time Iago can be very nice to a certain character while he conveys what he really feels to the audience through his soliloquys.

There are three prominent soliloquys that Iago has in the play. The first one is when Iago plans to deceive Rodorigo for his own purpose, taking over Cassio's position and having revenge on Othello: "Thus do I ever make my fool my purse. / For I mine own gained knowledge should profane / If I would time expend with such a snipe" (1.3.398-400), and saying that Rodorigo is a stupid person, so Iago feels that he does need to help a fool and gets something useful out of him instead. Then, Iago also directly conveys his hatred towards Othello: "I hate the Moor," (1.3.401) and tells the audience that he hears a rumor about Emilia sleeping with Othello. Although it is only a rumor, it is more than enough for Iago to hate Othello and bring the vicious plan to success. Also, from this soliloquy, Iago delivers not only his motivation to act in a complete evil way to other people, but also his decision to start ruining everyone's life, especially Othello and Cassio. He lays out his plan to the audience:

Cassio's a proper man. Let me see now:

To get his place and to plume up my will In double knavery. How? How? Let's see:

After some time, to abuse Othello's ears

That he is too familiar with his wife.

He hath a person and a smooth dispose

To be suspected, framed to make women false.

(1.3.407-413)
With this plan, Iago also recognizes Othello's strength and weakness that "The Moor is of a free and open nature." (1.3.414), showing that Othello can be innocent and believes others easily: "That thinks men honest that but seem to be so,/And will as tenderly beled by th' nose/As asses are." (1.3.415-417). Consequently, the plan is ready to go, because Iago believes that he has to be successful in bringing the "monstrous birth" (1.3.419).

The second soliloquy is when Iago expresses his jealousy towards the rumor about Othello and Emilia sleeping together. He thinks that Othello is a good husband, and Desdemona is loving, but Iago still needs to do the revenge: "I stand accountant for as great a sin / But partly led to diet my revenge." (2.1.310-311). Iago tries to stand for justice that he wants Othello to feel what he feels about the rumor: "Till I am evened with him, wife for wife." (2.1.316), letting Othello get drawn into jealousy towards the affairs between Desdemona and Cassio. Iago also emphasizes that people are not going to notice the plan until it is actually happening: "Knavery's plain face is never seen till used." (2.1.329).

The third soliloquy is about the handkerchief plan. Iago speaks to himself and tells the audience about what he is going to do with it. He is going to put the handkerchief in Cassio's place, so Othello is going to believe Iago's plan more than he expects. Iago emphasizes that the he is creating a great calamity that effects other people in a most painful way:

Dangerous conceits are in their nature poisons. Which at the first are scarce found to distate.

But with a little act upon the blood,

Burn like the minds of sulphur. I did say so: (3.3. 362-365)

Therefore, these soliloquys are important, because they show how Iago contributes to the plot development and how he directly tells the audience about his plan. Now that those soliloquys show the real Iago to the audience, they help the audience to see the reflection of Iago's qualities mentioned above: Iago as a backstabber, a trickster, and a master of exploiting the mind. Also, the soliloquys do not only reveal Iago's true self, but also maintain the idea of Machiavellian principle in Iago's traits that he has an extreme devilish side to fight against other people's lives, so that he can achieve the position he wants. 


\section{IAGO'S DEVILISH PERSONALITIES}

Having Iago's plan and soliloquys described, the analysis carries on with Iago's personalities, towards other characters. Iago's varied personalities are grouped into three major epitomes: Iago as a backstabber, a trickster, and a master of manipulating the mind. In terms of gaining power, these personalities are aligned with Machiavellian principles, saying that it is acceptable for a person to do whatever it takes in order to achieve and maintain one's existence in authority.

\subsection{Iago as a Backstabber}

When Machiavelli says the notion of power, Iago reflects it in his personality by being a backstabber. He does not care about what other people feel about it, but conducting his plan to create a reversal of fortune in their life. As one of the examples, Iago makes friends with Rodorigo until he is considered as Rodorigo's confidant. However, his friendship with Rodorigo is a part of his plan to take over Cassio's position. In front of Rodorigo, Iago is very convincing that he is going to help Rodorigo get Desdemona, while he actually takes the advantages of Rodorigo's weakness to fight for Desdemona by attacking Cassio.

Iago for once says to Rodorigo, "You, Rodorigo? Come, sir, I am for you." (1.2.70), showing himself to be a hypocrite in his friendship with Rodorigo, because he challenges Rodorigo to fight against him in front of others, while the plan in creating such a chaos is actually Iago's. By the end of Act 1, Iago has his first soliloquy to reveal his plan to manipulate Rodorigo by promising him that he can be with Desdemona while Iago takes the advantages of Rodorigo's money: "Thus do I ever make my fool my purse, / For I mine own gained knowledge should profane, / If I would time expend with such a snipe / But for my sport and profit." (1.3.398-401), demonstrating his motivation to make the use of Rodorigo.

\subsection{Iago as a Trickster}

A trickster is a person who deceives others, and Iago's ability in being a back stabber results in his great capability to be a deceitful speaker who convinces others with his sweet words, ready to twist the reality by his crafty plan. By any means, he creates many blemishes in other people's lives, making them feel uncertain about the truth. For instance, he gives a good description of Cassio to Montano that Cassio is a good soldier whose weakness is getting drunk while it is actually a part of his plan, making Cassio drunk. In fact, Iago says to Montano that he wants to help Cassio end his drinking problem: "I do love Cassio well, and would do much / To cure him of this evil" (2.3.144145), making Montano feels that Iago is loyal to Cassio, because Iago does not want to let Othello know if Othello chooses the wrong lieutenant.

\subsection{Iago as a Master of Manipulating the Mind}

One of Iago's strength is being a master of manipulating other's mind. He does this to manifest the idea of a Machiavellian character whose position matters more than the authority and legitimacy do. When others are not sure about Iago's words, Iago always finds a way to seal their doubt and convinces them that he is right. Even when they do something and feel wrong about it, Iago is showing his capability in steering other people's minds. The most obvious evidence of Iago as a master of manipulating the mind is his conversation with Othello, especially when Iago tries to dispel Othello's doubts on Desdemona's love affair with Cassio. At first, Iago acts in such a nervous way that he is about to spill the beans about Cassio. Iago keeps repeating Othello's questions until Othello feels if there is something wrong with people around him. Iago hypocritically states that Cassio is an honest man. However, because Othello senses Iago's agitation in saying the line, Othello pushes Iago to tell him the truth:

Nay, yet there's more in this.

I prithee speak to me as to thy thinkings.

As thou dost ruminate, and give thy worst of thoughts

The worst of words. (3.3.148-152)

Othello wants Iago to convey his suspicion of things between both Desdemona and Cassio. By saying those words, Othello's mind seems to start taking the rumor into a serious account. It surely becomes what Iago wants, having the opportunity to construct the fundamental element of his revenge and hatred towards Othello. Iago still plays the words by not being straightforward to Othello's demand on asking him to tell the truth. Iago says that he might have been falsely suspects the affair, but Othello convinces 
him again to reveal the truth. Iago is using a reversed psychology that he wants Othello to be aware of the consequences for Othello's peace of mind while Iago is actually starting to destroy it. When Othello says that he is going to find out about what Iago's thinking, Iago embraces his standpoint not to tell Othello, making Othello become curious. Nonetheless, Iago provides some facts about jealousy to Othello that jealousy is "the green-eyed monster which doth mock" (3.3.188) for it is going to make a husband start questioning his wife's faithfulness. Othello is upset when Iago expresses his thoughts about jealousy. He denies Iago's suspicion of Desdemona's affair, because Othello is sure that Desdemona is wide awake when she chooses Othello to be her husband and wonderful enough to be loyal to him: "I'll see before I doubt, when I doubt, prove. / And on the proof there is no more but this: / Away at once with love or jealousy." (3.3.213-215), demanding a proof to Iago about the affair. Although Othello is still in doubt, Iago has reached his goal to plant a certain kind of curiosity in Othello's mind that Othello is not going to stop thinking about it, so Othello's life is going to be miserable by being anxious all the time. Iago sees the anxiety from Othello's eyes and uses it as an opportunity to relate the truth with the nature, Desdemona's nature to be attracted to Italian guys instead of the Moor: "Her will, recoiling to her better judgment,/May fall to match you with her country forms,/And happily repent." (3.3.265-267), making Othello feels insecure about his marriage. Iago twists Othello's mind and imprints jealousy in Othello's heart.

\section{CONCLUSION}

From the analysis, it can be concluded that Machiavellian principles are applied in Iago's traits. The definition of rulership and the idea of force that comes into a form of virtù proposed by Machiavelli are aligned with Iago's motives in achieving power, and it results in the notion of Iago as a Machiavellian vice.

Iago thinks that he is the right person for Cassio's position, so he wants to take it over, and in doing so; Iago shows the idea of Machiavellian virtù. He demonstrates that it is acceptable to create a calamity towards other people's lives in order to gain power. Moreover, Iago is a master of manipulating other people's mind. He appears to be his real self through his soliloquys. This implies that he has the ability to convince others in doing what he wants. The existence of other characters as his "allies" is also aligned with Machiavellian principles. Machiavelli believes that it is reasonable to stab each other's back.

Therefore, Iago's atrocious behaviour is obviously a proof of Machiavellian principles application throughout the story. Iago stabs other characters to gain power and constructs a catastrophe in other people's lives.

\section{BIBLIOGRAPHY}

Abrams, M.H. A Glossary of Literary Terms. $7^{\text {th }}$ Ed. Fort Worth, Texas: Harcourt Brace College Publishers, 1999. Digital File.

Baldick, Chris. "Machiavel." The Oxford Dictionary of Literary Terms. Oxford University Press, 2008. Web. 6 August 2013. <http://www.oxfordreference. com/views/ENTRY.html?subview=Main\&E ntry $=\mathrm{t} 56 . \mathrm{e} 680>$

Bate, Jonathan and Eric Rasmussen. "Keyfacts." Othello. By William Shakespeare. Ed. Jonathan Bate and Eric Rasmussen. RSC Edition. Basingtoke: Macmillan, 2009. Print.

Bate, Jonathan and Eric Rasmussen. "Shakespeare's Career in the Theatre". Othello. By William Shakespeare. Ed. Jonathan Bate and Eric Rasmussen. RSC Edition. Basingtoke: Macmillan, 2009. Print.

Gauss, Christian. Introduction. The Prince. By Niccolo Machiavelli. New York: The New American Library of World Literature Inc., 1952. Print.

Hebron, Malcolm. Key Concepts in Renaissance Literature. Basingtoke: Palgrave

Machiavelli, Niccolò. The Prince and The Art of War. London: CRW Publishing Limited, 2004. Print.

"Machiavellian." Merriam Webster Online. Merriam Webster, n.d. Web. 13 February 2015.Macmillan, 2008. Print.

Nederman, Cary. "Niccolò Machiavelli." The Stanford Encyclopedia of Philosophy. Ed. Edward N. Zalta. Web. 18 February 2015.

Shakespeare, William. Othello. Ed. Jonathan Bate and Eric Rasmussen. RSC Edition. Basingtoke: Macmillan, 2008. Print. 
A Study of Speech Acts in Computer Products Advertisements

Wells, Stanley. "Shakespeare's Comedies" The New Cambridge Companion to Shakespeare. Ed. Margreta de Grazia and Stanley Wells. Cambridge: Cambridge University Press, 2001. 105-119. 